\title{
Design of a digital communication platform to food donations
}

\section{Diseño de una plataforma digital de comunicación para la donación de alimentos}

\author{
RAMOS-GONZÁLEZ, Luz María†*, GÓMEZ-MÉNDEZ, Elisa Itzel, CUENCA-LERMA, José \\ Manuel and LAGUNA-CAMACHO, Juan Rodrigo
}

Universidad Veracruzana, Faculty of Mechanical and Electrical Engineering

ID $1^{\text {st }}$ Author: Luz María, Ramos-González / ORC ID: 0000-0002-8658-2472, Researcher ID Thomson: G-1385-2019, CVU CONACYT ID: 972621

ID $1^{\text {sr }}$ Co-author: Elisa Itzel, Gómez-Méndez / ORC ID: 0000-0002-5043-3731, Researcher ID Thomson, CVU CONACYT ID: 1034093

ID $2^{\text {nd }}$ Co-author: José Manuel, Cuenca-Lerma / ORC ID: 0000-0002-5236-6448, Researcher ID Thomson, CVU CONACYT ID: 1030753

ID $3^{\text {rd }}$ Co-author: Juan Rodrigo, Laguna-Camacho / ORC ID: 0000-0003-0974-5204, CVU CONACYT ID: 100845

DOI: $10.35429 / J U S D .2021 .20 .7 .24 .30$

Received: March 10, 2021; Accepted June 30, 2021

\begin{abstract}
In this paper, a communication strategy between the individuals involved in the donation and collection of food is presented and thus, in this way, reduce the loss or waste of the same, which is one of the causes of food insecurity in Mexico and in the world. The platform is implemented as a distributed computing system. The system is accessed through a mobile application that operates on Android. The server implements the PHP language and stores the information in a relational model using the MySQL manager. In addition, the communication between the client and the server is done through the REST protocol encapsulating the data in JSON In this system, donors can see the location of nearby altruistic organizations, consult information and contact them through social networks. (WhatsApp, Facebook, and Twitter). It also publishes donation offers for organizations to contact them and view reports of donations made. Organizations visualize the offer of users and contact them through social networks. Likewise, they must record the follow-up of each donation received in order to ensure the delivery of the food.
\end{abstract}

Food insecurity, Communication platform, Food waste or loss

\begin{abstract}
Resumen
En el presente trabajo se presenta una estrategia de comunicación entre los individuos involucrados en la donación y recolección de alimentos y así, de esta forma reducir la pérdida o desperdicio de estos que es una de las causas de la inseguridad alimentaria en México y en el mundo. La plataforma se implementa como un sistema computacional distribuido. Se tiene acceso al sistema a través de una aplicación móvil que opera en Android El servidor se implementa mediante el lenguaje PHP y almacena la información en un modelo relacional utilizando el gestor de MySQL. Además, la comunicación entre el cliente y el servidor se realiza mediante el protocolo REST encapsulando los datos en JSON. En este sistema, los donadores pueden ver la ubicación de las organizaciones altruistas cercanas, consultar información y contactarlos a través de redes sociales. (WhatsApp, Facebook y Twitter). También publica ofertas de donativos para que las organizaciones los contacten y visualizan reportes de los donativos realizados. Las organizaciones visualizan la oferta de los usuarios y los contactan a través de las redes sociales. Asimismo, deben de registrar el seguimiento de cada donativo recibido con la finalidad de asegurar la entrega del alimento.
\end{abstract}

Inseguridad alimentaria, Plataforma de comunicación, Desperdicio o pérdida de alimentos

Citation: RAMOS-GONZÁLEZ, Luz María, GÓMEZ-MÉNDEZ, Elisa Itzel, CUENCA-LERMA, José Manuel and LAGUNA-CAMACHO, Juan Rodrigo. Design of a digital communication platform to food donations. Journal of Urban and Sustainable Development. 2021. 7-20: 24-30

\footnotetext{
*Correspondence to the author (e-mail: luzramos01@uv.mx)
}

$\uparrow$ Researcher contributing as first author 


\section{Introduction}

Food insecurity is one of the main worldwide problems, due to the inability of families to acquire nutritious food, which is reflected in the hunger and malnutrition of their members. One of the main causes of this issue, in addition to poverty, is the waste or loss of food at all levels and phases of the food chain. Some of the actions that are being carried out is the creation of food banks that are non- lucrative which dedicate to the collection of food that later donate to the people who need it most, for them they establish alliances with medium and large companies, as well as individuals who intend to support by making financial or in-kind donations.

Consequently, it is proposed a project where the objective is to design a communication platform between people who can donate food with the organizations that are dedicated to providing it to population sectors with food security problems, reducing the levels of waste of food in Mexico.

The first section describes what food insecurity is, as well as the loss and waste of food, later it is explained about the realization of the design and architecture of the system to finally expose by means of an example the operation of the application.

It is important to mention that this platform is intended to support the reduction of food waste and therefore support families with food insecurity problems through communication between the parties involved.

\section{Food Insecurity}

One of the most difficult problems for humanity to combat is food shortages and malnutrition. Although food production in some countries has increased, the number of hungry people has also grown, this is due to rapid population growth, coupled with inadequate food distribution.

The Food and Agriculture Organization of the United Nations (FAO) has defined that: "food security exists when all people have physical and economic access at all times to sufficient safe and nutritious food to satisfy their dietary needs and preferences in regarding food in order to lead an active and healthy life" (FAO, 1996).
On the contrary, food insecurity is defined as "the limited or uncertain availability of nutritionally adequate and safe food; or the limited and uncertain ability to acquire adequate food in socially acceptable ways" (Shamah-Levy, Mundo-Rosas, \& RiveraDommarco, 2014).

Poverty is the root cause of food insecurity since it can be the cause of unemployment or insufficient income that does not allow us to buy food. To guarantee household food security, it is necessary to improve nutritional status at the family level (Figueroa-Pedraza, 2003).

\section{Food Wasting}

Eradicating hunger and malnutrition are one of the great challenges that are currently faced worldwide, its consequences not only manifest in poor health, but also in other areas such as education and employment. To combat this situation, in 2015 the world community adopted the 17 Sustainable Development Goals in order to improve wellness by 2030. In this paper we focus on the Second Goal (Zero Hunger). In that sense, the intention of that goal is to end hunger, achieve food security, improve nutrition and promote sustainable agriculture. (Programa Mundial de Alimentos (WFP), 2021) Food loss and waste can occur at all levels and in every phase of the food chain from production to consumption.

This phenomenon can be analyzed from 2 points of view: the nutritional and environmental approach. The former is lost before it fulfills its function of nourishing humans and the latter is about some food that can be seen as waste. FAO takes the first approach by distinguishing between food loss and waste. "If food is discarded at any stage prior to consumption, it is loss; if the reduction occurs in the final phase of consumption, it is about waste".

The loss and waste of food not only represents a loss of the opportunity to feed the population, but its reduction is an important step to combat hunger and improve the level of nutrition of the most disadvantaged populations. Every year, more than 1.3 billion tons of food are wasted around the world, which is one third of global production.

RAMOS-GONZÁLEZ, Luz María, GÓMEZ-MÉNDEZ, Elisa Itzel, CUENCA-LERMA, José Manuel and LAGUNA-CAMACHO, Juan Rodrigo. Design of a digital communication platform to food donations. Journal of Urban and Sustainable Development. 2021 
This, in monetary terms, represents close to 1 trillion euros in economic costs, 700,000 million euros in environmental costs and around 900,000 million euros in social costs. (Hidalgo \& Martín-Marroquín, 2020) The total amount of food wasted reaches 20 million tons per year in Mexico. That amount, according to the Bank of Mexico, could cover the food demand of at least 7.3 million Mexicans living in poverty and generate income of 400 billion pesos. (NOTIMEX, 2018)

Nowadays, various actions are being carried out, among which the food banks stand out. The Food Bank of Mexico is one of the most recognized organizations in charge of promoting the creation of food banks in entities with an incidence of poverty. In addition, it rescues products from the field, supply centers, self-service stores, packing houses, etc. The purpose is to distribute them in the associated food banks. (Banco de Alimentos de México, 2014).

Food banks have alliances with big companies and startups that donate food (Nestlé, Alpura, Femsa, Bimbo, Gamesa, among others) (Banco de Alimentos de México, 2021) to later distribute it to those who need it most. However, it is reported that the greatest food waste occurs among consumers who are often unaware of the location of these organizations or the way to communicate with them. They also do not know the people who may have or need these foods.

Therefore, the purpose of this paper is to build a digital communication platform between people who can donate food with organizations that are dedicated to providing it to sectors of the population with food insecurity problems. In this way it will reduce the levels of food waste in Mexico.

\section{Methodology}

Based on the fact that reducing food loss and waste helps reduce the problem of Food Insecurity. Consequently, this project aims to contribute to the strengthening of food security through the reduction of food waste in the country by connecting people in situations of food insecurity with whom they can donate food to reduce food waste in Mexico.
The controlled variables correspond to characteristics of the community donation platform. Moreover, the variables to be observed measure the experience of using the platform and the amount of food wasted by users.

\section{Controlled Variables}

- $\quad$ Platform Access: refers to the strategy by which participants offer their food donations.

- Identification of Organizations: refers to the strategy used to find out the organizations with which the donation can be made.

- Identification of Risk Zones: refers to the strategy used to know the areas in which donations are delivered.

- Communication mediums: corresponds to the strategy used to establish communication between donors and specialized organizations.

\section{Variables to be Observed}

- User experience: corresponds to the perception that users of the platform have about its use. Its purpose is to determine the strategy with greater acceptance by the users of the controlled variables.

- $\quad$ Food Wasting: refers to the monthly amount of food that participants who use the platform waste.

\section{Platform Design}

The automation of the community food donation process is developed as a distributed computer system which is called "¿Usted Gusta?". The architecture of this system is client-server (Figure 1).

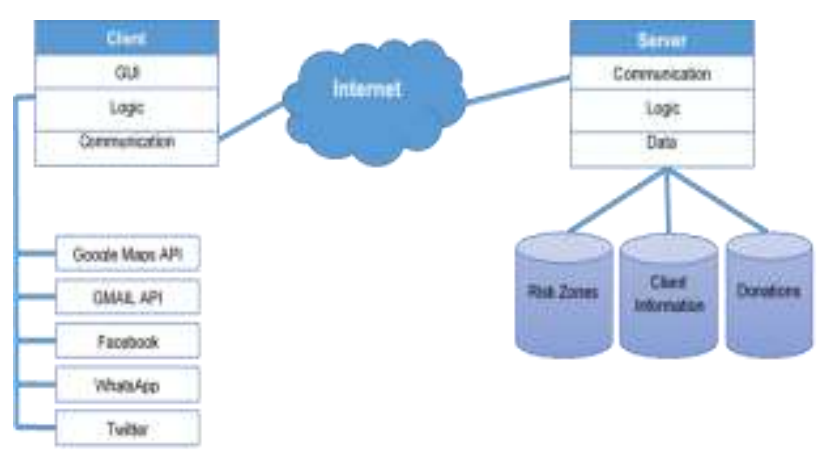

Figure 1 System Architecture Own Elaboration 
The client is a mobile application for users and organizations that receive donations. Likewise, it is a web application for the system administrator. All the information is stored in a central server which is a computational device where all the information of the system is stored and is retrieved by the client using web communication protocols.

The system includes three actors: users, organizations and the administrator. Each of them interacts with the system in a different way, their respective use cases are shown in figure 2, 3 and 4. It is important to mention that WhatsApp, Facebook and Twitter were chosen as means of communication among customers for the reason that these systems are already consolidated in this area.

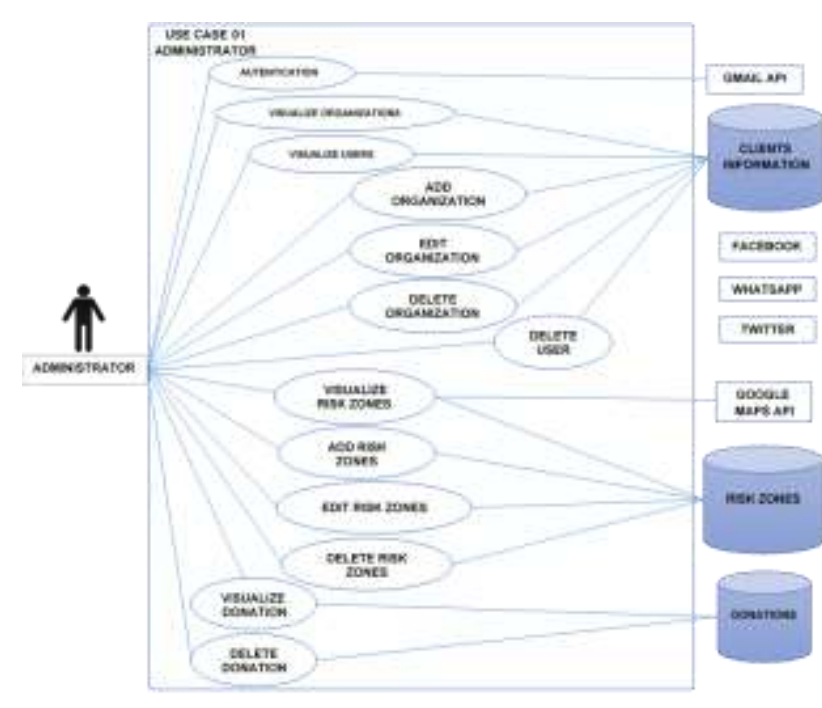

Figure 2 Use Case of Administrator Role Own Elaboration

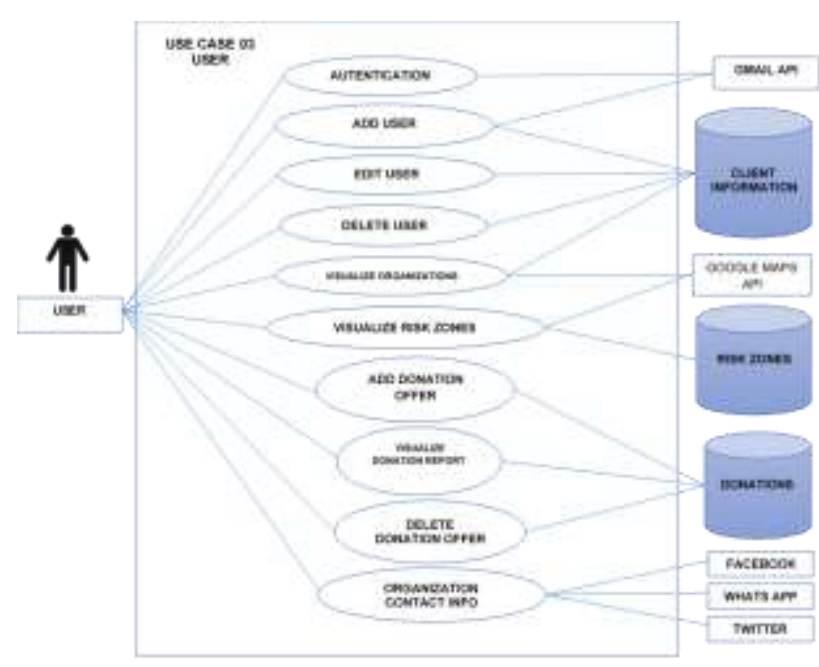

Figure 3 Use Case of Organization Role Own Elaboration

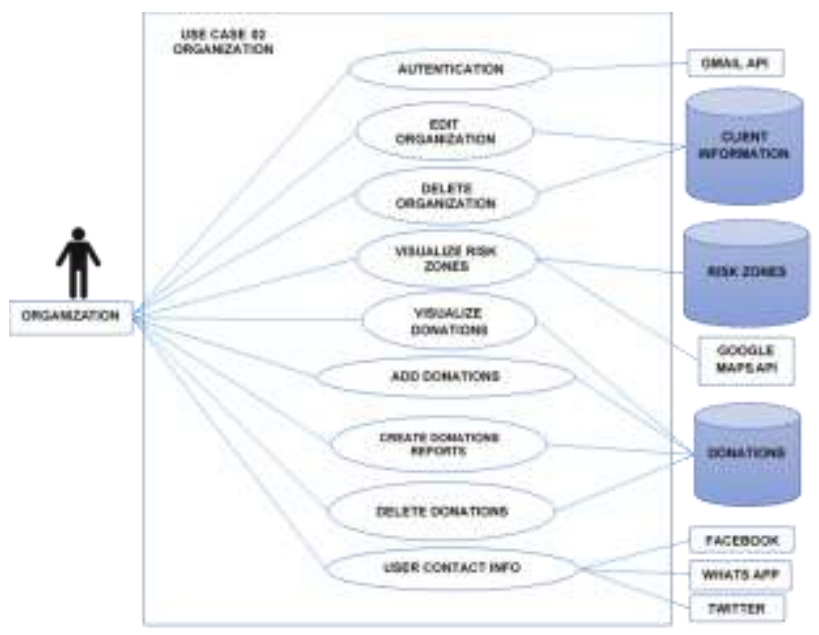

Figure 4 Use Case of User Role Own Elaboration.

\section{Platform Implementation}

The technology to develop the system is described in table 1.

\begin{tabular}{|c|c|c|c|}
\hline & $\begin{array}{c}\text { Android } \\
\text { App }\end{array}$ & Web App & Server \\
\hline Backend & Java & JavaScript & PHP \\
\hline Frontend & XML & \begin{tabular}{|l} 
HTML5, \\
CSS3
\end{tabular} & - \\
\hline $\begin{array}{l}\text { Communication } \\
\text { Protocols }\end{array}$ & POST & \begin{tabular}{|ll} 
GET & $\mathrm{y}$ \\
POST & \\
\end{tabular} & \begin{tabular}{|ll} 
GET $\quad y$ \\
POST
\end{tabular} \\
\hline \multicolumn{4}{|l|}{ Data Encapsulation } \\
\hline APIs & \begin{tabular}{|l|} 
Google \\
Maps API, \\
GMAIL API
\end{tabular} & $\begin{array}{|ll|}\text { Google } \\
\text { Maps API, } \\
\text { GMAIL API }\end{array}$ & CURL \\
\hline External Services & $\begin{array}{l}\text { Facebook, } \\
\text { WhatsApp, } \\
\text { Twitter }\end{array}$ & 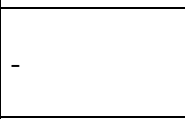 & - \\
\hline Data Storage & SQLite & - & MySQL \\
\hline $\begin{array}{l}\text { Platform } \\
\text { Publication }\end{array}$ & Google Play & Hosting Web & $\begin{array}{l}\text { Hosting } \\
\text { Web }\end{array}$ \\
\hline
\end{tabular}

Table 1 Technology to Implement the System

For the first prototype, the mobile application (Client) runs on the Android operating system. The supported versions are from 4.4 onwards. Therefore all 3 layers were developed with Kotlin using the Android Studio IDE. In addition, for users who do not have this operating system, a multiplatform web interface is developed using HTML5, CSS3 and JavaScript.

The server is implemented using the PHP language and stores the information in a relational model using MySQL. In addition, the communication between client and server is carried out through the REST protocol encapsulating data in JSON and through SHA 256 encryption. 


\section{Results}

It is implemented a distributed computer system which operates everywhere and every time.

\section{System Use Scenarios}

To understand the system functioning, we will assume that Manuel uses the software to donate food and Elisa uses it to manage the donations received in her organization. In the role of Manuel, he represents both a citizen and a company.

Organizations Location: Manuel has roast chicken that he wants to donate to help those most in need. He enters the system and locates on a digital map the closest organizations that receive donations. Likewise, the system gives him the option of contacting them through social networks to prepare the details of his donation. (Fig. 5)

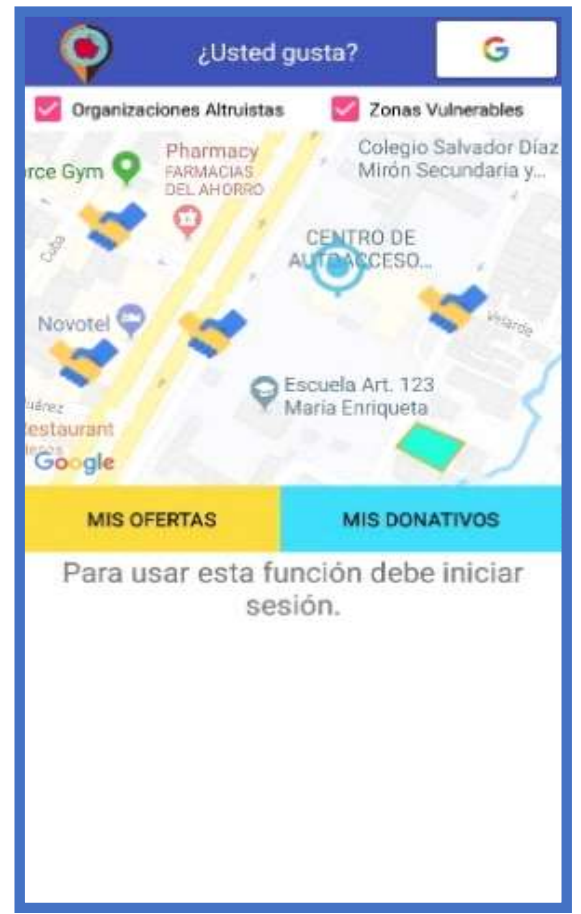

Figure 2 Organizations and Risk Zones Location Own Elaboration

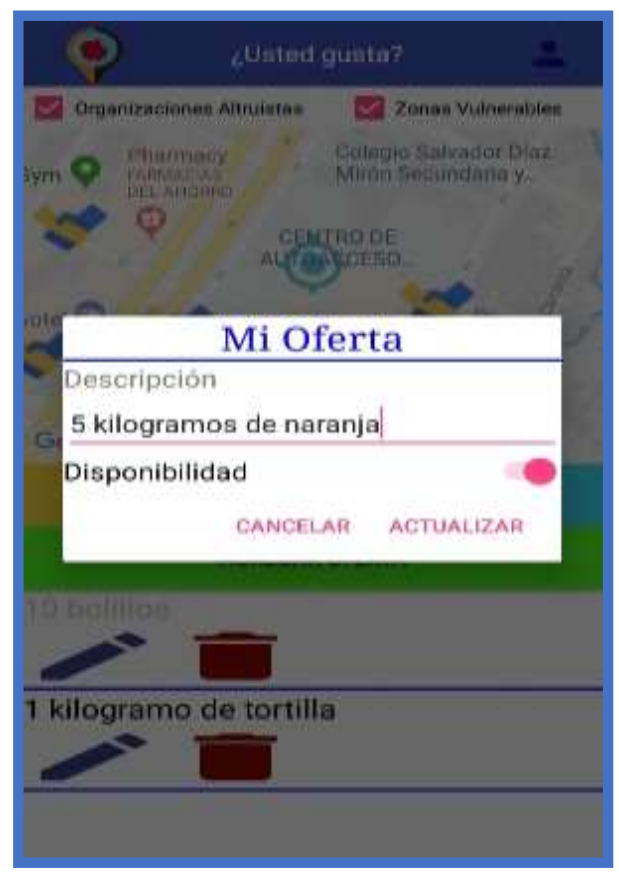

Figure 3 Registration of Donation Offer

Risk Zones Location: Manuel intends to donate the fruit that the trees in his yard give for the reason that he is not able to consume all of them. Also, he wants to go directly to the areas with food security problems, for this he enters the system and locates on a map the vulnerable areas. (Fig. 5)

Donations offer: Manual published in the system that he has $5 \mathrm{Kg}$ of orange to donate. Elisa reads the publication and contacts Manuel to offer the services of her organization regarding the donation. (Fig 6)

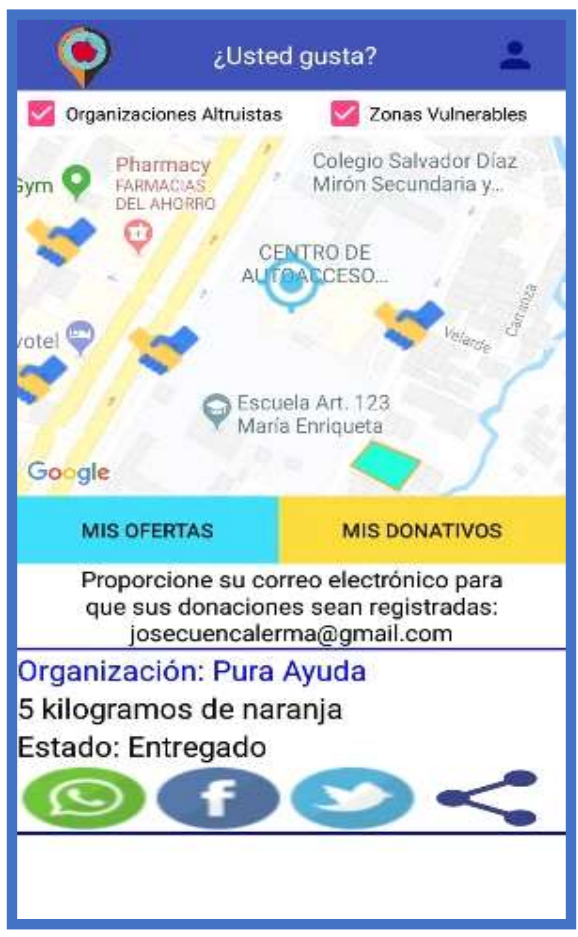

Figure 7 Viewing donations Own Elaboration

RAMOS-GONZÁLEZ, Luz María, GÓMEZ-MÉNDEZ, Elisa Itzel, CUENCA-LERMA, José Manuel and LAGUNA-CAMACHO, Juan Rodrigo. Design of a digital communication platform to food donations. Journal of Urban and Sustainable Development. 2021 
Donation Tracking: When Elisa receives the donation. She records it in the system. In this way, Manuel can see the follow-up that she is giving to the donation. Therefore, Elisa agrees to register the place where the donation was delivered and back it up with photographic evidence. Also, Manuel can share his donation on social networks to invite more people to use the system. (Fig. 7)

Finally, in figure 8 we can see how an organization that is dedicated to collecting food can register donations.

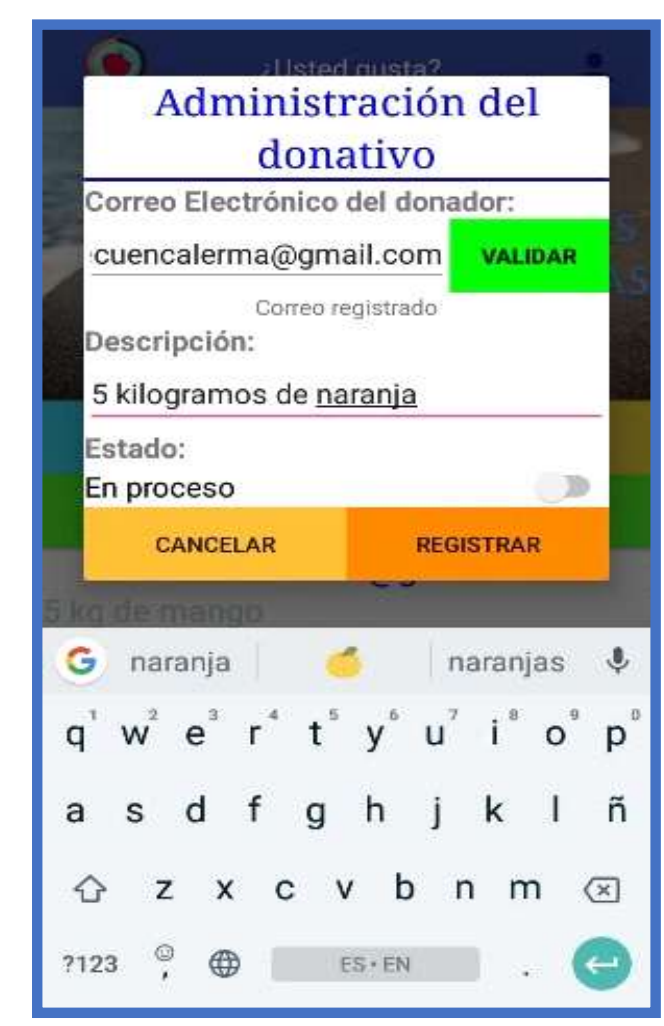

Figure 4 Register of an Organization Donations

\section{Conclusions}

Computer Technologies are used to develop "¿Usted Gusta?". This allows digitalization and automated processes obtaining information and communication as quickly as possible and making the food donation process as efficient as possible.

With the design of this platform, it is expected to obtain greater and better communication between the people who can donate food with the organizations that are dedicated to providing it to sectors of the population with food insecurity problems.
It is important to mention that this proposal is inviting the entire country to contribute to the task of achieving food security through the reduction of food waste, consequently, a collective synergy among citizens would be developing.

Therefore, the research contributes to the 2030 agenda of the SDGs, the development and implementation of this platform allows it to be a means of communication that speeds up the collection and distribution of food. In the same way that its projection and disclosure allow to transcend a greater number of the population, and which leads to an increase in the donation of food in an organized way since it would take control of the people who donate and those who benefit from this donation, as well as a decrease in the number of people who need food resources.

It is worth mentioning that at the beginning the approach of the platform " $¿$ Usted Gusta?" was based mainly on reducing waste and promoting a culture of food donation, currently it is intended that. For the second phase of development and updating, this approach changes and allows donation in a general way, that is, all kinds of donations (food, clothing, money, blood, etc.), as well as continuing to work towards achieving the SDGs of the 2030 agenda.

\section{References}

Banco de Alimentos de México. (2014). Banco de Alimentos en México. Obtenido de https://bamx.org.mx/?v=1fda4fa5605d.

Banco de Alimentos de México. (05 de 05 de 2021). Banco de Alimentos de México. Obtenido de Aliados:

https://www.bamx.org.mx/aliados/

Figueroa-Pedraza, D. (2003). Seguridad Alimentaria Familiar. Salud Pública y Nutrición.

Hidalgo, D., \& Martín-Marroquín, J. (2020). El desperdicio de alimentos. Un problema global. IndustriAmbiente, 28-33.

NOTIMEX. (15 de 05 de 2018). EXCELSIOR. México desperdicia 20 millones de toneladas de alimentos al año. 
Organización de las Naciones Unidas para la ALimentación y la Agricultura. (1996). Cumbre Mundial sobre la Alimentación. Plan de Acción de la Cumbre Mundial sobre la Alimentación. Roma.

Programa Mundial de Alimentos (WFP). (01 de 05 de 2021). Programa Mundial de Alimentos. Obtenido de Nuestra visión: 5 pasos hacia el Hambre Cero: https://es.wfp.org/hambre-cero

Shamah-Levy, T., Mundo-Rosas , V., \& Rivera-Dommarco, J. A. (2014). La magnitud de la inseguridad alimentaria en México: su relación con el estado de nutrición. Salud Pública de México, 79-85.

Urquía-Fernandez, N. (2014). La seguridad Alimentaria en México. Salud Pública de México, 92-98. 